гломерулонефрит; білковий та некротичний несроз; гіперемія і набряк легень

$\begin{array}{ccc}2 . & \text { у } & \text { випадках } \\ \text { експертизи зудово-ветеринарної } & \text { па підозри на отруєння тварин }\end{array}$

серцевими глікозидами доцільно ставити перед експертом вищенаведені запитання.

3. Подальшими дослідженнями необхідно встановити патоморфологію отруєнь серцевими глікозидами в інших видів тварин.

\title{
References
}

Batushkin, V. V., \& Solonynka, H. Ya. (2017). Zastosuvannia dyhoksynu v kardiolohichnii praktytsi. Kardyolohyia: ot nauky $k$ praktyke, 1, 53-70 (In Ukrainian).

Horalskyi, L. P., Khomych, V. T., \& Kononskyi, O. I. (2015). Osnovy histolohichnoi tekhniky i morfofunktsionalni metody doslidzhen u normi ta pry patolohii (Vyd. 3-ye, vypr. i dopov.). Zhytomyr: Polissia (In Ukrainian)

Zon, H. A., \& Ivanovska, L. B. (2012). Osnovy sudovo-veterynarnoi ekspertyzy otruien i toksykoziv tvaryn. Sumy: Mriia-1 (In Ukrainian)

Rouder Dzhozef, D. (2003). Veterynarnaia toksykolohyia. Moskva: Akvaryum Buk (In Russian).

Diadyk, A. I., Bahrii, A. Ye., Halaieva, Ya. Yu., \& Diadyk, I. O. (2003). Suchasni uiavlennia pro mekhanizmy di sertsevykh hlikozydiv. Liky, 3(4), 32-37 (In Ukrainian).

Cardiac Glycosides Poisoning in Dogs. Retreieved from https://wagwalking.com/condition/cardiac-glycosides-poisoning

\section{ASSESSMENT OF CONFORMITY TO THE LEGISLATION OF HONEY SAMPLES OF DIFFERENT VARIETIES OF BOTANICAL ORIGIN}

\author{
S. A. Tkachuk, S. V. Bilyk \\ National University of Life and Environmental Sciences of Ukraine, Kyiv, Ukraine \\ E-mail: ohdin@ukr.net
}

The Ukrainian market sells honey of different botanical origin, there are at least 30 titles (buckwheat, locust tree, rapeseed, sunflower, clover, lime tree and others).

Today, bee honey is enough to meet the needs of a wide range of consumers. However, the attractive price of a product often leads to the appearance of counterfeit or poor-quality honey. Therefore, when it is implemented in various trading networks, it is necessary to carry out an assessment of quality, and to prevent the occurrence of counterfeit to the consumer.

The purpose of the work is to investigate the honey of various botanical origin by physical and chemical indices.

The task of the study is to establish the conformity of the investigated samples of honey of different botanical origin to the requirements of the current DSTU 4497:2005 Natural honey. Technical conditions for physical and chemical indicators.

Materials for research were selected samples of honey of different botanical origin: flower, sunflower, acacia, buckwheat and grass.

Tests of honey samples for research were conducted according to DSTU 4497: 2005 Natural honey. Technical conditions.

The investigated honey samples of color and other organoleptic parameters corresponded to the current standard. Thus, the flavor was specific, pleasant, without foreign smells, well pronounced, delicate, depending on the botanical origin of honey. The taste of samples of honey of different botanical origin was sweet, tender, pleasant, irritating the mucous membrane of the oral cavity, without foreign flavors. By consistency, samples of honey were, in most cases, liquid and viscous. Symptoms of fermentation and mechanical impurities are not established.

According to physico-chemical parameters, samples of honey of different botanical origin corresponded to those specified in DSTU 4497: 2005 Natural honey. Technical conditions. At the same time, in the sample of the buckwheat honey, the indicator of the mass fraction of sucrose was $6,44 \pm 0,12 \%$, which is $1,07 \%$ and $2,9 \%$ higher than the requirements of the current standard for honey 1 and higher the brand.

The content of sucrose characterizes honey from the standpoint of its maturity, benignity and may be one of the indicators of botanical origin. The increased rate of sucrose may contribute to the implementation of insufficiently mature, counterfeit sugar, or sugar honey. For falsification of honey by sucrose, its organoleptic properties deteriorate, diastase activity decreases, mineral content and invert sugar decreases, and the sucrose content rises. We believe that the investigated honey samples are obtained due to insufficient maturation.

In our study, based on the values of hydroxymethylfurfural content, only samples of acacia honey and honey from herbs corresponded to the higher grade, the rest - to the first. According to the electrical conductivity only samples of flower honey and honey from different herbs responded to the highest grade, the rest - to the first. According to the values of proline content, honey samples from buckwheat and herbs corresponded to the higher grade of the others for the first.

Key words: honey, monophloric, polyphloric, national standard. 


\title{
ОЦІНКА ВІДПОВІДНОСТІ ЗАКОНОДАВСТУ ЗРАЗКІВ МЕДУ НАТУРАЛЬНОГО РІЗНОГО БОТАНІЧНОГО ПОХОДЖЕННЯ
}

\author{
С. А. Ткачук, С. В. Білик \\ Національний університет біоресурсів і природокористування України, Київ, Україна \\ E-mail: ohdin@ukr.net
}

За результатами дослідження встановлено, що всі досліджувані зразки меду відповідали вимогам чинного ДСТУ 4497:2005 Мед натуральний. Технічні умови, окрім зразків гречаного меду, в яких масова частка

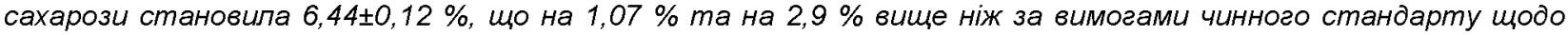
меду 1 та вищого гатунку, відповідно.

Iз досліджуваних зразків меду різного ботанічного походження вищому гатунку відповідали зразки меду з різнотрав'я.

Ключові слова: мед, монофрлорний, поліфлорний, національний стандарт.

\section{Вступ}

Актуальність теми. Мед є цінним харчовим продуктом i, зважаючи на його властивості предметом внутрішньодержавної та світової торгівлі, які за останні п'ять років зросли на $18 \%$, досягнувши в 2017 p - 690,3 тис. тонн загальною вартістю 2,37 млрд. доларів (Burka, 2018). Станом на 2018 рік $80 \%$ меду (57 тис. тон із 70 тис), який виробляється в Україні іде на експорт. У січні за 11 днів від початку року Україна вичерпала квоту експорту меду до $€ C$. Разом 3 тим, актуальним питанням залишається збільшення експортних можливостей України та відповідність зразків меду вимогам національного та європейського законодавства.

Аналіз останніх досліджень і публікацій. Нині існує інтегрована система контролю за безпечністю харчових продуктів, що виконується єдиним органом, подібно до діючої міжнародної системи контролю. Це впроваджується для можливості простежити за всіма ланками виробництва харчових продуктів «від лану до столу» (Ponomarev, 2006; Pyslar, 2012).

В Україні не діють жодні обов'язкові вимоги до якості меду, а існуючий держстандарт $\epsilon$ добровільним. У рамках Угоди про асоціацію Україна взяла на себе зобов'язання запровадити європейські вимоги до меду, які зафіксовано в Директиві Ради 2001/110/ЄС, до кінця 2019 року (Dyrektyva Rady YeS, 2012).

За даною Директивою ЄC мед не повинен містити будь-яких доданих компонентів, включно харчові добавки, та будь-які інші складники, ніж ті, що властиві цьому продукту. Також вимоги до безпечності і якості харчових продуктів, зокрема меду, викладені в Codex Standard for Haney (Codex Alimentarius) 12-1981 та інших нормативно-правових документах (Rehlament Yevropeiskoho Parlamentu, 2002; Rehlament № 853/2004, 2004; Rehlament № 854/2004, 2004)

Для здійснення експортних операцій усі країни повинні дотримуватися та контролювати речовини та їх залишкові кількості, які вказані у директиві 96/23 ЄС від 26 квітня 1996 року «Про заходи для моніторингу деяких речовин та їхніх залишків у живих тваринах і продуктах тваринного походження» (Dyrektyva Rady, 1996).

Отже, зрозуміло, що дотримання вимог до якості меду та його безпечності вітчизняними виробниками $\varepsilon$ обов'язковими для здійснення експортних операцій та збуту продукту в межах України.
На ринку України реалізується мед різного ботанічного походження, існує не менше 30 назв (гречаний, білоакацієвий, ріпаковий, соняшниковий, конюшиновий, липовий та інші). Також гарним медоносом $€$ фундук, але він міститься у незначній кількості у поліфлорному меді (Demchenko, 2014).

Мед класифрікують і за угіддями, на яких бджоли збирають нектар: польовий, лісовий, різнотравний тощо. Тому споживачі мають великий вибір медів, які відрізняються за консистенцією, кольором, ароматом та іншими ознаками. Нині бджолиного меду $\epsilon$ достатньо для задоволення потреб широкого кола споживачів. Проте приваблива ціна на продукт часто приводить до появи фольсиффікованого або неякісного меду. Тому під час його реалізації в різних торгівельних мережах необхідно проводити оцінку якості, та не допускати потрапляння фальсифікату до споживача (Adamchuk, 2014; Brovarskyi, Losiev, \& Holovetskyi, 2011).

Mema роботи - дослідити мед різного ботанічного походження за фрізико-хімічними показниками.

Завдання дослідження - встановити відповідність досліджуваних зразків меду різного ботанічного походження вимогам чинного ДСТУ 4497:2005 Мед натуральний. Технічні умови за фрізико-хімічними показниками.

\section{Матеріал і методи досліджень}

Дослідження виконувались в Українській лабораторії якості і безпечності продуктів АПК, с.м.Т. Чабани, Київської області, у відділі моніторингу якості згідно плану щодо написання магістерської роботи.

Матеріалом для дослідження слугували відібрані зразки меду різного ботанічного походження: квітковий, соняшниковий, акацієвий, гречаний та з різнотрав'я.

Випробування зразків меду для дослідження проводились за ДСТУ 4497:2005 Мед натуральний. Технічні умови.

\section{Результати досліджень та їх обговорення} Згідно ДСТУ 4497:2005 визначали органолептичні показники зразків меду - колір, запах, смак, кристалізацію, консистенцію, ознаки бродіння та наявність механічних домішок.

Колір меду $\epsilon$ одним 3 найважливіших факторів, що зумовлюе його якість. Ботанічне походження меду, мінеральний та хімічний склад, можливе його нагрівання можуть впливати на колір. 
Колір меду зумовлений рослинними пігментами, такими як хлорофріл, каротин, ксантофріли та жовтозеленими кольоровими пігментами. За чинним стандартом мед може мати білий, світло-жовтий, темно-жовтий, темний кольор з різними відтінками та бути безкольорним. У світовій науковій літературі наводяться результати дослідження щодо класифікації кольорів меду (кольоровий індекс) за методами, заснованими на оптичному порівнянні (Aubert, \& Gonnet, 1983). Вказується, що колір меду пов'язаний із вмістом пилку, сумарних фенолів, мінеральним складом та вмістом гідроксиметилфурфуролу і характерний для того чи іншого ботанічного походження (Gonzalez-Miret,
Terrab, Hernanz, Fernandez-Recamales, \& Heredia, 2005; Bertoncelj, Doberśek, Jamnik, \& Golob, 2007).

Досліджувані зразки меду за кольором та за іншими органолептичними показниками відповідали чинному стандарту. Так аромат був специфічним, приємним, без сторонніх запахів, добре вираженим, ніжним, залежно від ботанічного походження меду. Смак зразків меду різного ботанічного походження був солодким, ніжним, приємним, подразнював слизову оболонку ротової порожнини, без сторонніх присмаків. За консистенцією зразки меду були, у більшості, рідкими та в'язкими. Ознак бродіння і механічних домішок не встановлено. Отримані фрізико-хімічні показники зразків меду представлені в таблиці 1.

Таблиця 1

Фізико-хімічні показники зразків квіткового, соняшникового, акацієвого, гречаного меду та 3 різнотрав'я $(\mathrm{M} \pm \mathrm{m}, \mathrm{n}=3)$

\begin{tabular}{|c|c|c|c|c|c|}
\hline \multirow[t]{2}{*}{ Показники } & \multicolumn{5}{|c|}{ Зразки меду } \\
\hline & квітковий & СОняЩнИковиЙ & акацієвий & гречаний & з різнотрав'я \\
\hline $\begin{array}{l}\text { Результат пилкового } \\
\text { аналізу }\end{array}$ & $\begin{array}{l}\text { Наявність } \\
\text { пилкових } \\
\text { зерен }\end{array}$ & $\begin{array}{l}\text { Наявність } \\
\text { пилкових зерен }\end{array}$ & $\begin{array}{l}\text { Наявність } \\
\text { пилкових зерен }\end{array}$ & $\begin{array}{l}\text { Наявність } \\
\text { пилкових } \\
\text { зерен }\end{array}$ & $\begin{array}{l}\text { Наявність } \\
\text { пилкових } \\
\text { зерен }\end{array}$ \\
\hline $\begin{array}{l}\text { Масова частка води, } \\
\%\end{array}$ & $16,70 \pm 0,10$ & $16,30 \pm 0,10$ & $15,20 \pm 0,05$ & $15,80 \pm 0,02$ & $16,50 \pm 0,03$ \\
\hline $\begin{array}{l}\text { Масова частка } \\
\text { відновлюваль- } \\
\text { них сахарів (до } \\
\text { безводної речовини), } \\
\%\end{array}$ & $98,33 \pm 0,07$ & $93,01 \pm 0,14$ & $81,88 \pm 0,33$ & $78,91 \pm 0,04$ & $89,99 \pm 0,03$ \\
\hline $\begin{array}{l}\text { Масова частка } \\
\text { сахарози (до } \\
\text { безводної речовини), } \\
\%\end{array}$ & $1,44 \pm 0,07$ & $3,28 \pm 0,27$ & $2,48 \pm 0,17$ & $6,44 \pm 0,12$ & $2,45 \pm 0,02$ \\
\hline $\begin{array}{l}\text { Діастазне число (до } \\
\text { безводної } \\
\text { речовини), од. Готе }\end{array}$ & $16,80 \pm 0,04$ & $15,33 \pm 0,04$ & $10,66 \pm 0,06$ & $15,70 \pm 0,01$ & $18,01 \pm 0,10$ \\
\hline $\begin{array}{l}\text { Вміст гідроксиметил- } \\
\text { фурфуролу (ГМФ), мг } \\
\text { на } 1 \text { кг }\end{array}$ & $14,5 \pm 0,10$ & $11,20 \pm 0,05$ & $7,20 \pm 0,10$ & $14,8 \pm 0,10$ & $9,10 \pm 0,10$ \\
\hline $\begin{array}{l}\text { Кислотність, } \\
\text { міліеквіваленти } \\
\text { гідроокису натрію }(0,1 \\
\left.\text { моль/дм }{ }^{3}\right) \text { на } 1 \text { кг }\end{array}$ & $22,78 \pm 0,26$ & $15,43 \pm 0,41$ & $16,76 \pm 0,85$ & $14,58 \pm 0,37$ & $15,87 \pm 0,12$ \\
\hline $\begin{array}{l}\text { Вміст проліну, мг на } 1 \\
\text { кг }\end{array}$ & $266,44 \pm 0,53$ & $237,55 \pm 1,08$ & $208,19 \pm 0,85$ & $359,60 \pm 0,45$ & $386,60 \pm 1,41$ \\
\hline $\begin{array}{l}\text { Електропровідність, } \\
\text { мС/см }\end{array}$ & $0,86 \pm 0,12$ & $1,08 \pm 0,05$ & $1,34 \pm 0,09$ & $1,10 \pm 0,02$ & $0,79 \pm 1,15$ \\
\hline $\begin{array}{l}\text { Якісна реакція на } \\
\text { наявність паді }\end{array}$ & Негативна & Негативна & Негативна & Негативна & Негативна \\
\hline
\end{tabular}

За фізико-хімічними показниками зразки меду різного ботанічного походження відповідали зазначеним у ДСТУ 4497:2005 Мед натуральний. Технічні умови [12]. Разом з тим, у зразку гречаного меду показник масової частки сахарози становив $6,44 \pm 0,12 \%$, що на $1,07 \%$ та на 2,9\% вище, ніж за вимогами чинного стандарту щодо меду 1 та вищого ґатунку, відповідно.
Відомо, що сахароза $є$ складним цукром дисахаридом. Це звичайний цукор, який ми вживаємо в їжу. Його добувають з цукрового буряку або цукрової тростини. В різних видах бджолиного меду його міститься від 1,3 до $5 \%$, а іноді зовсім немає. Вміст сахарози характеризує мед з позицій його зрілості, доброякісності і може бути одним 3 показників ботанічного походження. Підвищена 
норма сахарози може сприяти реалізації недостатньо зрілого, фальсисрікованого цукром, або цукрового меду. За фальсифікації меду сахарозою погіршуються його органолептичні властивості, знижується діастазна активність, вміст мінеральних речовин і інвертного цукру, а кількість сахарози підвищується. Однак вміст сахарози у бджолиному меді не може розглядатися як основний критерій його натуральності і $€$ тільки показником ступеня його дозрівання (Polishchuk, Losiev, \& Holovetskyi, 2013).

За вимогами ДСТУ 4497:2005 вміст цукрів у меді може коливатися для сахарози від 3,5 \% - для меду вищого гатунку і до $6 \%$ - для 1 ґатунку. Вимоги стандартів $€ С$ передбачають вміст сахарози на рівні $5 \%$. За гармонізації вимог за цим показником доцільно буде залишити його на рівні європейських нормативів. Уміст відновлювальних сахарів, як найціннішого показника якості меду, в національних стандартах практично на $20 \%$ перевищують вимоги стандартів $\epsilon C$, що $\epsilon$ одним із елементів захисту внутрішнього ринку від неякісного імпорту

Тому ми вважаємо, що досліджувані зразки меду отримано за недостатнього його дозрівання.

Важливою характеристикою якості меду вважають вміст гідроксиметилфурфуролу (ГМФ). Відповідно до вітчизняних вимог, у меді допускається до $25 \mathrm{мг/кг} \mathrm{ГМФ,} \mathrm{а} \mathrm{в} \mathrm{країнах} \mathrm{ЄС} \mathrm{та}$ СОТ цей показник не повинен перевищувати 15 мг/кг (для меду хлібопекарського значення ГМФ не повинно бути більшим, ніж 40 мг/кг). У нашому дослідженні за показниками вмісту гідроксиметилфурфуролу лише зразки акацієвого меду та меду з різнотрав'я відповідали вищому ґатунку (ДСТУ), решта - першому.

За вимогами ДСТУ електропровідність натурального меду вищого ґатунку - 0,2-1,0 $\mathrm{mCм} / \mathrm{cm}$, першого ґатунку - 0,2-1,5 мСм/см, тоді як за міжнародними вимогами - не більше ніж 0,8 $\mathrm{mCm} / \mathrm{cm}$. За показниками електропровідності досліджуваних зразків меду можна зробити висновок про його ботанічне походження, відрізнити падевий мед від нектарного. За міжнародними вимогами до електропровідності меду $(0,8 \mathrm{mCм} / \mathrm{cm})$ не можна достовірно стверджувати його ботанічне походження. У нашому дослідженні за показниками електропровідності лише зразки квіткового меду та меду з різнотрав'я відповідали вищому ґатунку (ДСТУ), решта - першому.

За показниками вмісту проліну зразки меду гречаного та різнотрав'я відповідали вищому ґатунку, решта - першому

1. Усі досліджувані зразки меду відповідали вимогам чинного ДСТУ 4497:2005 Мед натуральний. Технічні умови, окрім зразків гречаного меду, в яких масова частка сахарози становила $6,44 \pm 0,12 \%$, що на $1,07 \%$ та $2,9 \%$ вище, ніж за вимогами чинного стандарту щодо меду 1 та вищого ґатунку, відповідно.

2. Із досліджуваних зразків меду різного ботанічного походження вищому ґатунку відповідали зразки меду з різнотрав'я.

3. Вимогам чинного стандарту щодо вищого ґатунку не відповідали зразки акацієвого та соняшникового меду за показниками електропровідності, та вмісту проліну, квіткового за вмістом проліну та гідроксиметилфурфуролу.

Burka, A. (2018). Obsiahy torhivli medom za ostanni piat rokiv zrosly. Agronews. Retreieved from https://agronews.ua/node/91921 (in Ukrainian).

Ponomarev, A. (2006). Kontrol kachestva meda v myrovom pchelovodstve. Bdzhilnytstvo, 7, 60-63. [in Ukrainian].

Pyslar, H. V. (2012). Yakist produktsii bdzhilnytstva: svitovyi dosvid ta vitchyzniana praktyka. Zhurnal ZhNAU, 2, 296307 (in Ukrainian).

Dyrektyva Rady YeS 2001/110 vid 20 hrudnia 2001 r. «Stosovno medu». (2012). Official Journal of the European Communities, 10, 47-52.

Rehlament Yevropeiskoho parlamentu i Rady (178/2002/ES) vid 28 sichnia 2002 roku: shchodo vstanovlennia zahalnykh pryntsypiv ta vymoh zakonodavstva pro kharchovi produkty, zasnuvannia Yevropeiskoho orhanu kharchovo bezpeky i vstanovlennia protsedur u sferi bezpeky kharchovykh produktiv. Retreieved from http://uww.icqc.eu/userfiles/File/178 2002.pdf.

Rehlament (leS) Yevropeiskoho Parlamentu i Rady (№ 853/2004) vid 29 kvitnia 2004 roku : pro vstanovlennia konkretnykh hihiienichnykh pravyl dlia kharchovykh produktiv tvarynnoho pokhodzhennia. Retreieved from http://zakon4.rada.gov. ua/laws/show/994 a99

Rehlament (leS) Yevropeiskoho Parlamentu i Rady (№ 854/2004) vid 29 kvitnia 2004 roku: pro vstanovlennia konkretnykh pravyl orhanizatsii ofitsiinoho kontroliu produktiv tvarynnoho pokhodzhennia, pryznachenykh dlia spozhyvannia liudynoiu. Retreieved from http://zakon4.rada.gov.ua/laws/show/994 a67

Dyrektyva Rady 96/23/leS vid 29 kvitnia 1996 r. Pro zakhody dlia monitorynhu deiakykh rechovyn ta yikhnikh zalyshkiv u zhyvykh tvarynakh i produktakh tvarynnoho pokhodzhennia ta skasuvannia Dyrektyv 85/358/leES i 86/469/leES ta Rishen 89/187/leES i 91/664/leES. Retreieved from http://www.fsvps.ru/fsvps-docs/ru/laws/eu/96-23.pdf.

Demchenko, N. (2014). Funduk - nadrannii produktyvnyi pylkonos. Pasika, 3, 4-6.

Adamchuk, L. (2014). Kharakterystyka soniashnykovoho medu riznykh rehioniv Ukrainy. Kharchova promyslovist ahropromyslovoho kompleksu, 6, 34-39 (in Ukrainian).

Brovarskyi, V. D., Losiev, O. M., \& Holovetskyi, I. I. (2011). Yakist riznykh sortiv bdzholynoho medu torhovoi merezhi $\mathrm{m}$. Kyieva. Naukovyi visnyk Lvivskoho natsionalnoho universytetu veterynarnoi medytsyny ta biotekhnolohii. S.Z. Hzhytskoho: Zb. nauk prats, 13, 2(48), 330-335 (in Ukrainian).

Med naturalnyi : DSTU 4497: 2005. - [Chynnyi vid 2007-01-01]. (2007). Kyiv.: Derzhspozhyvstandart of Ukraine (in Ukrainian).

Aubert, S. \& Gonnet, M. (1983). Mesure de la couleur des miels. Apidologie, 14, 105-118.

Gonzalez-Miret, M. L., Terrab, A., Hernanz, D., Fernandez-Recamales, M. A., \& Heredia, F. J. (2005). Multivariate correlation between color and mineral composition of honey and their botanical origin. Journal of Agricultural and Food Chemistry, 53, 2574-2580. 
Bertoncelj, J., Doberśek, U., Jamnik, M., \& Golob, T. (2007). Evaluation of the phenolic content, antioxidant activity and colour of Slovenian honey. Food Chemistry, 105, 822-828.

Polishchuk, V. P., Losiev, O. M., \& Holovetskyi, I. I. (2013). Tekhnolohiia oderzhannia bdzholynoho medu ta metody laboratornoho doslidzhennia yoho yakosti. Metodychni rekomendatsii. Kyiv: Vipol (in Ukrainian).

\title{
FORENSIC INSPECTION OF SOUL-MILK CHEESE ON MATERIALS CRIMINAL PROCEEDINGS
}

\author{
I. V. Yacenko \\ Kharkiv State Zooveterinary Academy, Kharkiv, Ukraine \\ E-mail: vacenko-1971@ukr.net
}

\begin{abstract}
The materials of pre-trial investigation of criminal proceedings and materials of forensic inspection of sour-milk cheese on the fact of supplying this counterfeit product to budget educational institutions have been used in the article. The algorithm to conduct forensic inspections of soul-milk cheese has been developed, it includes: transferring to the investigator expert materials of the case and material evidence, the inspection by the expert of documents (materials of the case), the determination of the normative basis regulating the indicators of safety and quality of the cheese and its turnover, the research of labeling elements of the product, the laboratory research of the products, the analysis of the results of the laboratory research of sour-milk cheese, the preparation of the conclusion of the inspection.

The samples of sour-milk cheese, investigated during the forensic inspection, can not be identified as sour milk cheese, because they did not meet the requirements of State Standard 4554: 2006 "Sour-milk cheese. Specifications" due to the content of non-recipe components and lower titrated acidity of the product. This may be due to the addition of vegetable oils in the process of its production or any other inhibitors that suppress the livelihoods of lactic acid bacteria in the
\end{abstract}

product (antibiotics, disinfectants, etc.) and prevent its peroxidation during storage, and accordingly, extend the term of implementation; or the production of sourmilk cheese was made from raw materials that were not of dairy origin. In this regard, the samples of the above products should be considered falsified.

Consequences for human health that can be caused by the consumption of the products - fatty mixtures depend on many factors, including microbial contamination of the fatty mixture, the presence of antibiotics, pesticides, heavy metals, radionuclides, and other xenobiotics (these indicators were not indicated by the expert analyzed), indicators of safety and quality of milk and non-dairy raw materials (for example, the type of vegetable oils) from which the fatty mixture is made, the health of people who use such fatty mixtures for a long period of time, etc.

The consumption of sour-milk cheese that does not meet the requirements of the national standards for this product can lead to cardiovascular and cancer diseases, ovulation infertility, Alzheimer's disease, etc. (due to the high level of trans-isomers) and also the food poisoning.

Key words: sour-milk cheese, vegetable oils, falsification, forensic inspection, baby food.

\section{СУДОВА ЕКСПЕРТИЗА СИРУ КИСЛОМОЛОЧНОГО ЗА МАТЕРІАЛАМИ КРИМІНАЛЬНОГО ПРОВАДЖЕННЯ}

\author{
І. В. Яценко \\ Харківська державна зооветеринарна академія, м. Харків, Україна \\ E-mail: vacenko-1971@ukr.net
}

\begin{abstract}
У статmі детально проаналізовано матеріали досудового розслідування кримінального провадження та матеріали судової експертизи сиру кисломолочного за фрактом постачання иього фральсифрікованого продукту до бюджетних закладів освіти. Розроблено алгоритм проведення судових експертиз сиру кисломолочного

Ключові слова: сир кисломолочний, жир рослинного походження, фальсифікація, судова експертиза, дитяче харчування.
\end{abstract}

\section{Вступ}

За останні роки спостерігається тенденція до зростання зареєстрованих випадків розслідування правопорушень відповідними органами, пов'язаних 3 реалізацією на території України продуктів харчування, які виготовленні 3 порушеннями відповідних вимог, що стосуються їх складових елементів та характерних властивостей, які зазначені у нормативно-технічній документації України, щуо регламентують показники безпечності і якості відповідної продукції (Petrova, 2015; Sychev,
2015; Egorov, Mardar, 2009; Dmitrichenko, 2003; Kravtsiv, \& Hachak, 2003).

Проаналізувавши дані факти, можна зазначити, що однією із важливих причин такої ситуації, особливо в молочній галузі $€$ недосконала система державного контролю за виробництвом та умовами реалізації даної групи товарів (Kyryliuk, \& Kyryliuk, 2017). Також вагомий вплив на дану проблему мають безпосередньо самі виробники молока і молочних продуктів. Ставлячи собі за мету лише отримання прибутку, в основному, за рахунок 